\title{
Response of Ustilago maydis against the Stress Caused by Three Polycationic Chitin Derivatives
}

\author{
Dario Rafael Olicón-Hernández ${ }^{1}$, Cristina Uribe-Alvarez ${ }^{2}$, Salvador Uribe-Carvajal ${ }^{2}$, \\ Juan Pablo Pardo ${ }^{3}$ and Guadalupe Guerra-Sánchez ${ }^{1, *}$ \\ 1 Instituto Politécnico Nacional, Escuela Nacional de Ciencias Biológicas, Departamento de Microbiología, \\ Prolongación de Carpio y Plan de Ayala S/N, Col. Sto. Tomas, Del, Miguel Hidalgo, \\ CP 11340 Ciudad de México, Mexico; magnadroh@hotmail.com \\ 2 Universidad Nacional Autónoma de México, Instituto de Fisiología Celular, Circuito exterior S/N, \\ Ciudad Universitaria, CP 04510 Ciudad de México, Mexico; curibe@email.ifc.unam.mx (C.U.-A.); \\ suribe@ifc.unam.mx (S.U.-C.) \\ 3 Universidad Nacional Autónoma de México, Facultad de Medicina, Departamento de Bioquímica, \\ Circuito exterior S/N, Ciudad Universitaria, CP 04510 Ciudad de México, Mexico; pardov@bq.unam.mx \\ * Correspondence: lupegs@hotmail.com; Tel.: +52-55-5729-6000 (ext. 62339)
}

Received: 10 August 2017; Accepted: 13 October 2017; Published: 7 December 2017

\begin{abstract}
Chitosan is a stressing molecule that affects the cells walls and plasma membrane of fungi. For chitosan derivatives, the action mode is not clear. In this work, we used the yeast Ustilago maydis to study the effects of these molecules on the plasma membrane, focusing on physiologic and stress responses to chitosan $(\mathrm{CH})$, oligochitosan $(\mathrm{OCH})$, and glycol-chitosan $(\mathrm{GCH})$. Yeasts were cultured with each of these molecules at $1 \mathrm{mg} \cdot \mathrm{mL}^{-1}$ in minimal medium. To compare plasma membrane damage, cells were cultivated in isosmolar medium. Membrane potential $(\Delta \psi)$ as well as oxidative stress were measured. Changes in the total plasma membrane phospholipid and protein profiles were analyzed using standard methods, and fluorescence-stained mitochondria were observed. High osmolarity did not protect against $\mathrm{CH}$ inhibition and neither affected membrane potential. The $\mathrm{OCH}$ did produce higher oxidative stress. The effects of these molecules were evidenced by modifications in the plasma membrane protein profile. Also, mitochondrial damage was evident for $\mathrm{CH}$ and $\mathrm{OCH}$, while $\mathrm{GCH}$ resulted in thicker cells with fewer mitochondria and higher glycogen accumulation.
\end{abstract}

Keywords: chitosan; oligochitosan; glycol-chitosan; Ustilago maydis; stress response

\section{Introduction}

Ecological niches for fungi are numerous and varied. In nature, fungi can be found as saprophytic agents, as pathogenic or phytopathogenic parasites, as communities (mycorrhiza), or as symbionts [1]. Thus, fungi are exposed to different environmental stress conditions such as variations in $\mathrm{pH}$, temperature, osmolarity, toxins, and natural or synthetic compounds that could damage their structure or disrupt their metabolism and yet, they survive [2]. Stress in fungi may be an external biotic or abiotic condition that interferes with optimal growth parameters and generates physiological responses [3]. These defense responses may involve overexpression of genes related to carbohydrate metabolism [4], the production of structural proteins [5], modifications in cell wall or membrane composition [6,7], changes in cell integrity [4], and the production of reactive oxygen species (ROS) [8]. One of the advantages of studying stress responses in fungi is that they are excellent models of eukaryotic responses against external or internal factors which could also be observed in plants and animals; indeed, very conserved defense mechanisms exist [9]. 
Chitosan $(\mathrm{CH})$ elicits a strong stress response in fungi. It is a polycationic semi-natural carbohydrate with an average molecular weight of $50 \mathrm{kDa}$, constituted by the aminated sugars glucosamine $(<90 \%)$ and $N$-acetyl glucosamine $(>10 \%)$ [10]. The main source of chitosan is their extraction from chitin from insects and crustaceans; however, it also is an important constituent of green algae, yeasts, protozoa, as well as the cell walls of some fungi and used in the fabrication of environmentally friendly antimicrobial agents [11]. In this context, it was reported that $\mathrm{CH}$ and its derivatives are able to inhibit bacteria, fungi, and viruses that can generate diseases from the clinical and environmental point of view, mainly by boosting the immune systems of humans, animals, and plants, interfering with the normal metabolism of the pathogens, destroying cellular structures [12-14]. In acidic $\mathrm{pH}$, the $\mathrm{CH}$ amino groups are protonated and thus, $\mathrm{CH}$ is polycationic. It is used to produce different antimicrobial agents [15], such as oligochitosan (OCH) and glycol-chitosan (GCH), also polycationic in nature, which are applied in different industries and research activities. The $\mathrm{OCH}$ (MW around $5 \mathrm{kDa}$ ) is smaller than chitosan [16], while GCH is produced by etherification of chitosan and ethylene glycol and is used in bio-gel fabrication [12]. In contrast to $\mathrm{CH}$, which is soluble only at an acid $\mathrm{pH}$, both $\mathrm{OCH}$ and $\mathrm{GCH}$ are soluble at $\mathrm{pH}$ 7.0. The polycationic nature of these compounds allows strong interactions with different fungal structures such as the cell wall, membrane lipids, proteins, and nucleic acids, probably triggering a stress response [17]. In eukaryotic cells, chitosan and its derivatives promote morphological mechanical alterations [15], increased ROS concentration [18,19], mitochondrial dysfunction [20], decreased metabolic processes [21], decreased septation, increased spore mitoses [22], and overexpression of genes related to oxidative stress [23]. Fungi react to these polycations through proteins involved in plasma membranes, respiration, ATP production, and mitochondrial organization. In Neurospora crassa, the generation of reactive oxygen species, cellular energy, and cellular membrane homeostasis was affected by chitosan [21].

Ustilago maydis is a basidiomycete and an ustilaginal fungus used as a model species in several biochemical and physiological studies. Due to its accessible genome, easy handling, ability to grow in defined media by budding and formation of compact colonies on plates, $U$. maydis is considered an ideal fungal model for cell and molecular biology studies [24]. We have previously described the effects of $\mathrm{CH}, \mathrm{OCH}$, and $\mathrm{GCH}$ on the development and morphology of Ustilago maydis [15]. Here, we characterize the response of $U$. maydis to each of these polycationic compounds and conclude that each chitosan derivative triggers a specific stress-like response in $U$. maydis.

\section{Results}

\subsection{Growth of $U$. maydis at Different Osmolarities: Effects of $\mathrm{CH}, \mathrm{OCH}$, and $\mathrm{GCH}$}

In hypo-osmotic medium, $\mathrm{CH}$ inhibits the growth of $U$. maydis, while $\mathrm{OCH}$ and $\mathrm{GCH}$ have no effects [15]. Here, when culturing the cells in an isosmotic medium, the same inhibition pattern was observed (Figure 1), i.e., $\mathrm{OCH}$ and $\mathrm{GCH}$ did not exhibit any effect, while $\mathrm{CH}$ fully inhibited $U$. maydis growth.

\subsection{Cell Membrane Permeability Changes in $U$. maydis upon Addition of $\mathrm{CH}, \mathrm{OCH}$ or $\mathrm{GCH}$}

Since osmotic support to $U$. maydis did not prevent the chitosan effect, it was decided to determine whether the plasmatic membrane was intact. For this, the transmembrane electrical potential $(\Delta \psi)$ in the cell was estimated using a cyanine derivative [25]; $2 \mu \mathrm{g} \cdot \mathrm{mL}^{-1}$ of chitosan decreased $\Delta \psi$ by more than $50 \%$. Higher concentrations further decreased $\Delta \psi$ (Figure 2I). The presence of different polycation compounds $(\mathrm{OCH})$ and $(\mathrm{GCH})$ did not produce changes in this physiological parameter (Figure 2II,III). 


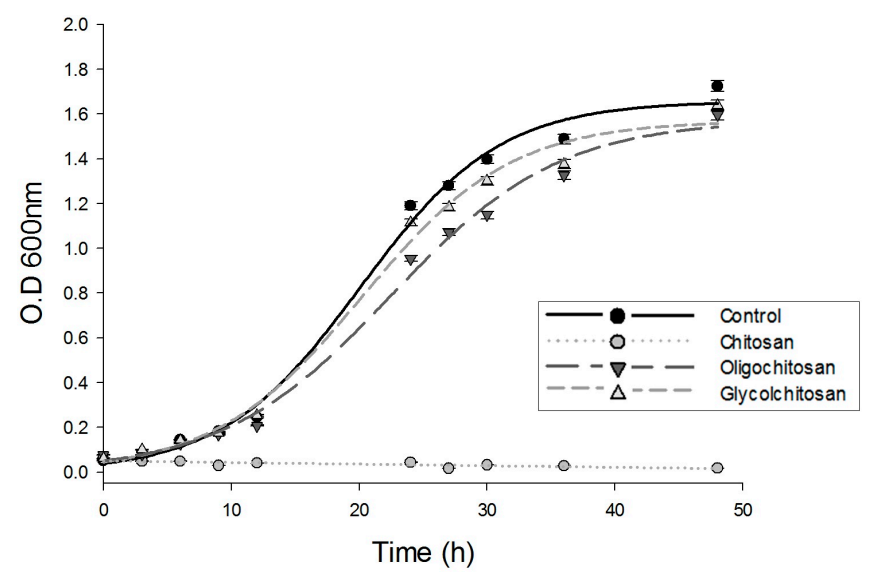

Figure 1. Growth of Ustilago maydis in minimal medium and in the presence of chitosan, oligochitosan or glycol-chitosan. Each agent was added to a final concentration of $1 \mathrm{mg} \cdot \mathrm{mL}^{-1}$. Growth was measured as an increase in optical density at $600 \mathrm{~nm}$.

I

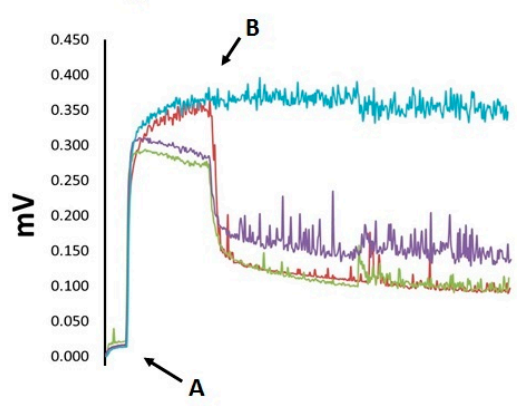

I I

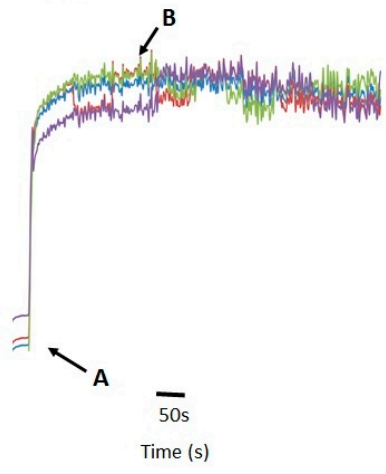

I I I

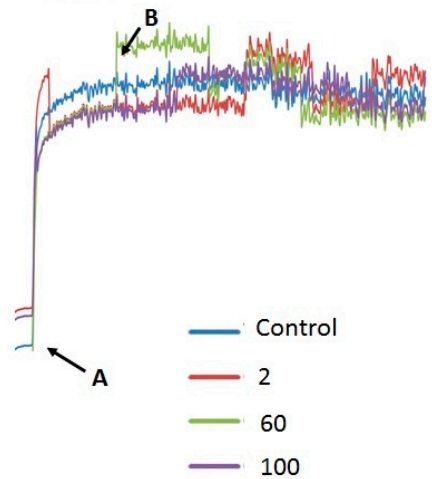

Figure 2. Changes in $\Delta \psi$ in response to different concentrations of $\mathrm{CH}, \mathrm{OCH}$ or $\mathrm{CGH}$. All concentrations are expressed in $\mu \mathrm{g} \cdot \mathrm{mL}^{-1}$. The numbers correspond to each antifungal tested, (I) $\mathrm{CH}$; (II) $\mathrm{OCH}$; (III) GCH. Additions were: A = cells; B = Antifungal. U. maydis, 25 mg wet weight.

\subsection{Determination of ROS Released by $\mathrm{U}$. maydis as a Response to $\mathrm{CH}, \mathrm{OCH}$ or $\mathrm{GCH}$}

The production/presence of ROS was measured directly (Amplex Red ${ }^{\circledR}$ method) and indirectly (catalase activity) after treatment with the different polycation compounds. During growth, the control cells produced $3.13 \mathrm{nmol}_{2} \mathrm{O}_{2} \mathrm{~min}^{-1} \mathrm{mg}$ wet weight ${ }^{-1}$, and the catalase-specific activity was $1.87 \mathrm{U} \mathrm{mg}$ protein ${ }^{-1}$, indicating that some hydrogen peroxide is formed under the physiological conditions and normal growth. Cells treated with chitosan produced considerably less $\operatorname{ROS}\left(0.11 \mathrm{nmol} \mathrm{H}_{2} \mathrm{O}_{2} \mathrm{~min}^{-1} \mathrm{mg}\right.$ of cell wet weight $\left.{ }^{-1}\right)$ and showed a catalase activity of $0.56 \mathrm{U} \mathrm{mg}$ of protein $^{-1}$. This is associated with immediate and total $\mathrm{CH}$-mediated cell destruction [15]. The OCH treatment produced a statistically significant increase in $\mathrm{ROS}\left(16.6 \mathrm{nmol} \mathrm{H}_{2} \mathrm{O}_{2} \mathrm{~min}^{-1} \mathrm{mg}\right.$ of cell wet weight ${ }^{-1}$ and catalase activity of $7.97 \mathrm{U} \mathrm{mg}$ of protein $^{-1}$ ), which means that it produced a greater amount of ROS compared to the other treatments. Cells grown in GCH did not show any differences in terms of ROS production $\left(5.75 \mathrm{nmol} \mathrm{H}_{2} \mathrm{O}_{2} \mathrm{~min}^{-1} \mathrm{mg}\right.$ of cell wet weight ${ }^{-1}$ and $2.19 \mathrm{U} \mathrm{mg}$ of protein ${ }^{-1}$ ) compared to the control cells; this was corroborated by the results of Tukey's test (Figure 3). 


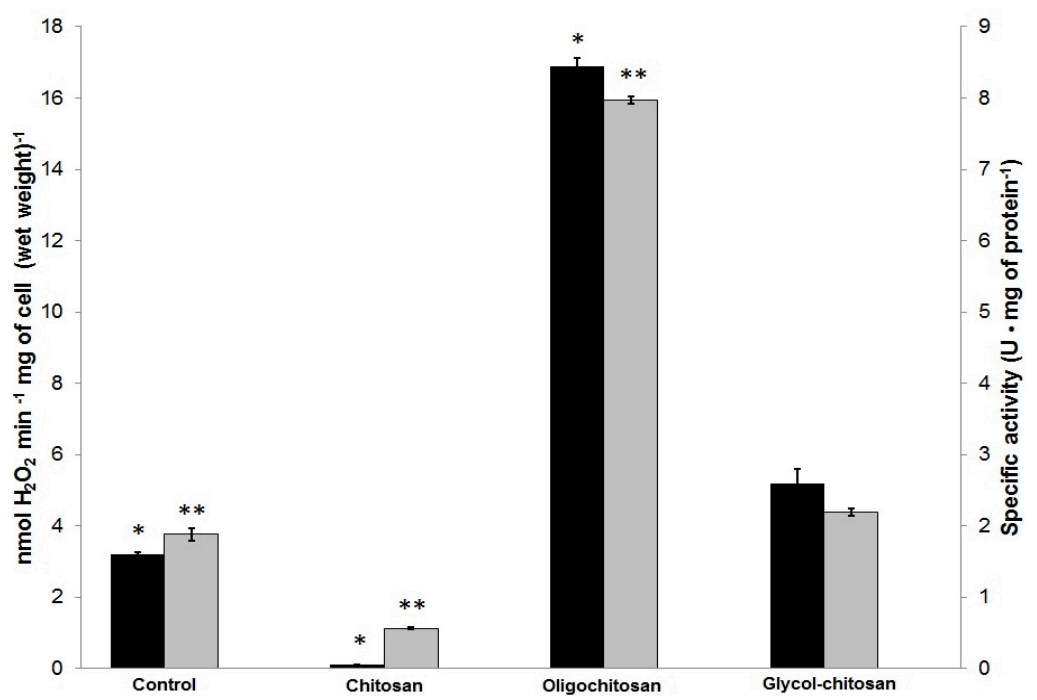

Figure 3. Quantification of ROS production by Ustilago maydis grown in the presence of $\mathrm{CH}, \mathrm{OCH}$ or $\mathrm{GCH} . \mathrm{H}_{2} \mathrm{O}_{2}$ production as measured with Amplex red $^{\circledR}(\boldsymbol{\square})$ and catalase activity $(\square)$. Cells were incubated in minimal medium for $24 \mathrm{~h}$ at $128 \mathrm{rpm}$ and the indicated antifungal agent was added at $1 \mathrm{mg} \cdot \mathrm{mL}^{-1}$. Significance was evaluated by one-way ANOVA analysis and Tukey test $(p<0.05)$. The experiments were performed in triplicate $(n=3)$. ${ }^{*}$ and ${ }^{* *}$ indicate significant difference in $\mathrm{H}_{2} \mathrm{O}_{2}$ production and catalase activity, respectively, compared to control cells.

\section{4. $\mathrm{CH}-, \mathrm{OCH}-$, or $\mathrm{GCH}-$ Mediated Damage of the Mitochondrial Structure in U. maydis}

Damages in the mitochondrial structure were observed by the use of Mitotracker green ${ }^{\circledR}$ (Invitrogen/Thermo Fisher Scientific, Waltham, MA, USA) via fluorescence microscopy. In all cases, background fluorescence was observed, but specific regions were stained with greater intensity when mitochondria were present, especially in the control cells (Figure 4A2). The mitochondrial staining of cells with $\mathrm{CH}$ and $\mathrm{OCH}$ (Figure 4B2,C2) showed irregular fluorescence distribution, suggesting high damage. Cells incubated in the presence of GCH exhibited a lower fluorescence intensity than the control cells (Figure 4D2), suggesting mitochondria loss.
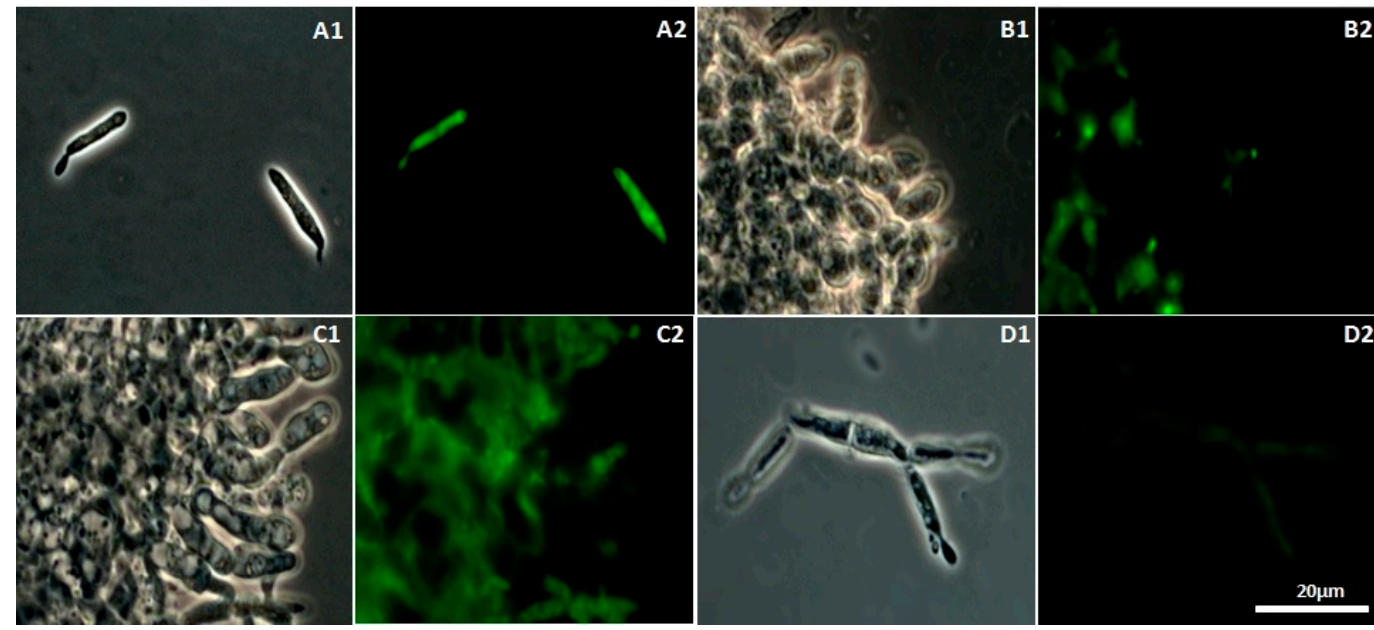

Figure 4. Phase contrast (1) and fluorescence (2) microscopy of $U$. maydis stained with MitoTracker ${ }^{\circledR}$ Green FM. An Eclipse E800 fluorescent microscope (Nikon Instruments Inc., Melville, NY, USA) with a fluorescein filter was used. The cells were growth in MM with the different treatment in a concentration of $1 \mathrm{mg} \mathrm{mL}^{-1}$. The intensity of the signal is according with the presence of the mitochondrial proteins. A = Control; $\mathbf{B}=$ Chitosan; C = Oligochitosan; D = Glycol-chitosan. Time of incubation of 24 h. 


\subsection{Chitin Derivatives Modify Total Phospholipid Contents}

As shown in Table 1, the phospholipid contents of the membrane fraction of yeast grown in the presence of chitin derivates were statistically decreased. The greatest decrease (44.72\%) was induced by oligochitosan, followed by glycol-chitosan with an approximated decrease by $17.78 \%$ compared to the control. There was no data for chitosan, due to its inhibitory effect on yeast growth.

Table 1. Total phospholipid concentration ( $\mathrm{mM}$ phospholipids $\mathrm{g}$ of cells $\mathrm{s}^{-1}$ ) in the membrane fraction of $U$. maydis growth under antifungal treatments.

\begin{tabular}{cc}
\hline Antifungal Tested (1) $\left.\mathbf{m g} \cdot \mathbf{m L}^{-\mathbf{1}}\right)$ & $\begin{array}{c}\text { Total Phospholipid Concentration (mM } \\
\text { Phospholipids } \mathbf{g} \text { of Cells }\end{array}{ }^{-\mathbf{1}}$ Wet Weight) \\
\hline Control & $4.54 \pm 0.035^{\mathrm{a}}$ \\
Chitosan & $\mathrm{ND}$ \\
Oligochitosan & $2.51 \pm 0.12^{\mathrm{b}}$ \\
Glycol-chitosan & $3.76 \pm 0.043^{\mathrm{c}}$
\end{tabular}

$\mathrm{ND}=$ Not determined. Different letters $(\mathrm{a}, \mathrm{b}$ and $\mathrm{c})$ indicate significant difference in one-way ANOVA evaluated by Tukey test $(p<0.05)$. The experiments were performed in triplicate $(n=3)$.

\subsection{SDS-PAGE Analysis of U. maydis Membrane Proteins in the Absence and Presence of $\mathrm{CH}, \mathrm{OCH}$ or GCH}

The SDS-PAGE analysis (Figure 5) was performed to observe the modification in the protein profile caused by the addition of chitin derivatives. In $\mathrm{CH}$-treated cells, the decrease in the intensity of a band near $100 \mathrm{kDa}$, suggested as the electrophoretic mark of the plasma membrane $\mathrm{H} \pm$ ATPase (band A) [26], was observed. The samples treated with OCH exhibited the largest changes, presenting a more intense protein band at approximately $90 \mathrm{kDa}$ (band C), $57 \mathrm{kDa}$ (Band D), and $14 \mathrm{kDa}$ (band E). The A band was not neatly distinguished as observed in the control cells. Cells grown in glycol-chitosan showed a well-delimited band A, with greater banding intensity in a protein of near $83 \mathrm{kDa}$ (Band G).

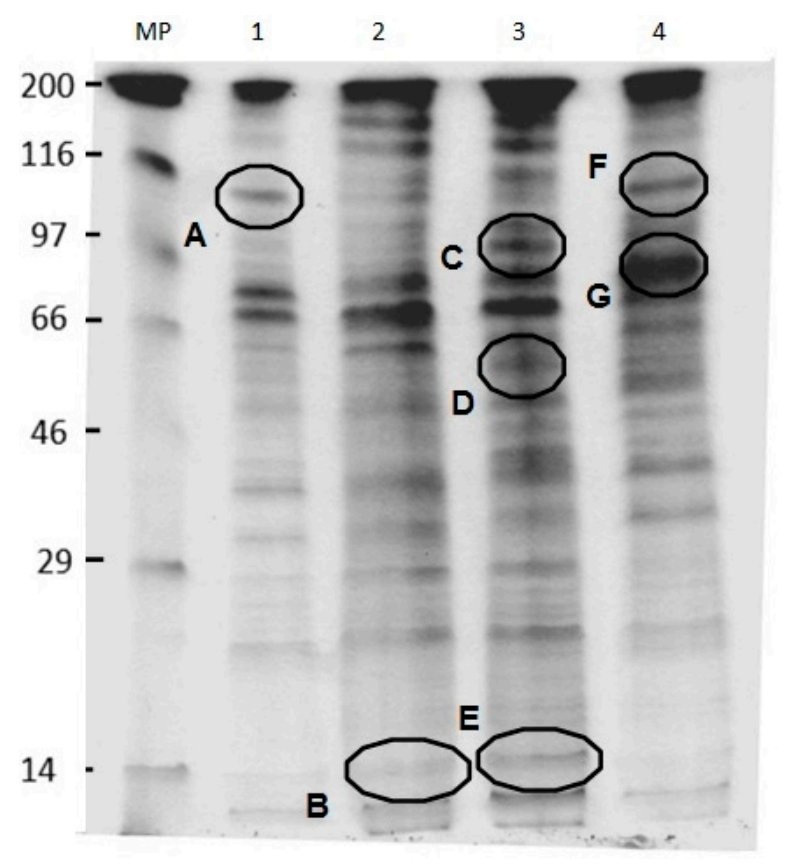

Figure 5. SDS-PAGE of the membrane fraction of $U$. maydis after the different antifungal treatments. Oligochitosan and glycol-chitosan were added at $1 \mathrm{mg} \cdot \mathrm{mL}^{-1}$. Chitosan was added at $10 \mu \mathrm{g} \cdot \mathrm{mL}^{-1}$ due to the effect on cell growth. MW= Molecular weight marker (KDa); 1 = Control cell without antifungals; 2 = Cells treated with chitosan; 3 = Cells treated with oligochitosan; 4 = Cells treated with glycol-chitosan. Squares indicate differences in the bands pattern. 


\subsection{Effects of $\mathrm{CH}, \mathrm{OCH}$ or $\mathrm{GCH}$ on the Accumulation of Glycogen by U. maydis}

In response to stress, bacteria and yeasts accumulate glycogen. The cells cultured in the presence of GCH accumulated glycogen as compared to the control (Figure 6A). No glycogen was detected by PAS staining of cells with $\mathrm{CH}$ and $\mathrm{OCH}$ (data not shown). Interestingly, cells with GCH showed an increased size compared to the control (Figure 6B). This abnormal glycogen accumulation suggests that metabolic changes may be activated to use the $\mathrm{GCH}$ as fuel storage, which induces cell thickening.

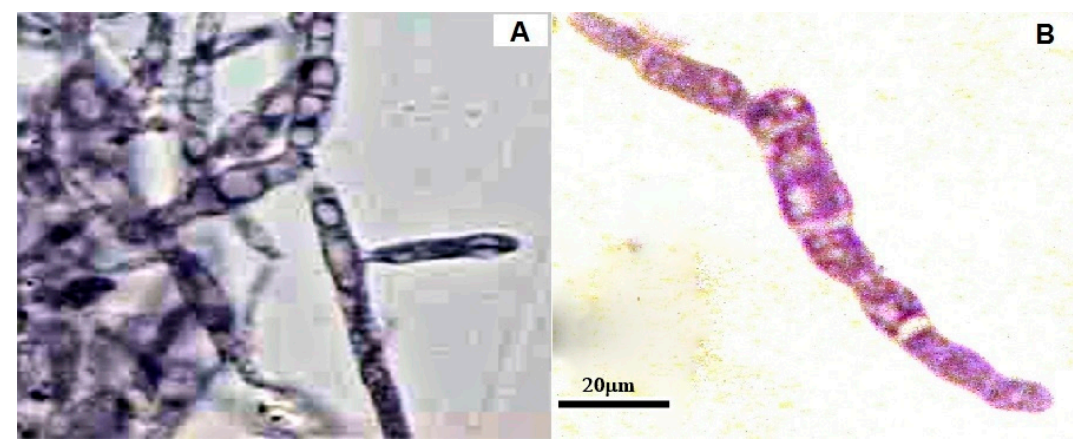

Figure 6. PAS staining of $U$. maydis in the presence of GCH. A $1 \mathrm{mg} \cdot \mathrm{mL}^{-1}$ of each antifungal compound was added. The positive schiff reaction was demonstrated by the presence of the purple compound derivate of the interaction between the basic fuchsin with aldehydes sugars. $(\mathbf{A})=$ Control; (B) = Glycol-chitosan $(100 \times)$.

\section{Discussion}

Adverse external conditions trigger the stress defense response that comprises diverse metabolic modifications needed for survival [27]. In $U$. maydis, different chitin derivatives prompted different responses. As our results show, high osmolarity did not modify the effects of the different derivatives tested, indicating that the findings observed for the fungus do not solely result from osmotic stress [15]. This observation stands in contrast to the evidence reported by Zakrzewska et al. [28], who observed that $1 \mathrm{M}$ sorbitol protected Saccharomyces cerevisiae cells against chitosan. The authors state that the high-osmolarity glycerol pathway is crucial to establish fungal sensibility to chitosan. In this regard, $U$. maydis does exhibit important differences in the activation and control of this pathway, which would explain its sensitivity to chitosan, even in an isosmolar environment $[28,29]$. As reported before, chitosan promotes has a complete inhibitory effect on Ustilago maydis as a consequence of the interaction between specific sites in the plasma membrane and protonated free amino groups, constituting the main change of the polymer [15]. The modifications in cell permeability explain the depletion of the membrane potential and are consistent with observations in Rhizopus stolonifer at a chitosan concentration of $2000 \mu \mathrm{g} \cdot \mathrm{mL}^{-1}[15,30]$. However, in a non-susceptible model, such as Candida albicans, the effect of chitosan on the plasma membrane is completely the opposite: Peña et al. [31] described hyperpolarization of the cell membrane of $C$. albicans due to an alignment of internal charges with a subsequent increase in potential membrane when the yeast was in the presence of low chitosan concentrations [31]. Thus, it is evident that the effects of chitosan vary depending on the model [32]. In this study, $\mathrm{OCH}$ and $\mathrm{GCH}$ did not affect the plasma membrane potential.

There is evidence of an enhancement of oxygen consumption in $R$ stolonifer, $C$. albicans, and $U$. maydis by chitosan and oligochitosan $[15,31,33]$. This modification of the rate of oxygen consumption could be due to an increased use of ATP, involved in energy-depended defense against these polymers, or to the generation of reactive oxygen species [31]. Oxidative stress in the presence of OCH has previously been described in macrophages, plant cells, and fungi $[16,18,34]$. In the last case, it was proposed that chitin derivatives inhibited proteins involved in the generation of reducing power for the neutralization of intracellular ROS, such as glutathione S-transferase-4 [34]. Our results do not indicate whether the formation of ROS is part of the oligochitosan antifungal effect or simply a response to 
the stress generated by these molecules. On the other hand, the addition of $\mathrm{CH}$ and $\mathrm{OCH}$ seems to disorganize the mitochondrial structure without affecting its function. In contrast, in U. maydis, GCH does affect mitochondrial function. Previously, we described the reduction in the oxygen consumption rate in $U$. maydis in the presence of $\mathrm{GCH}$ [15]. In the present work, we corroborated the affectation of the mitochondria by GCH; this result is consistent with the decrease in respiration in $U$. maydis by the addition of glycol-chitosan, which has been described previously [15]. We believe this is the first report on the mitochondrial effects of GCH.

In the presence of chitin derivatives, the responses of $U$. maydis, modifying its lipid, protein, and carbohydrate composition, are part of a global survival mechanism. The OCH modified the total phospholipids and, to a lesser extent, so did GCH. Additionally, the protein profile was modified by the presence of each of the compounds used. The stressors may interact with the plasma membrane and produce different signals that up-regulate different membrane proteins. The modification of the protein concentration and protein functionality during $\mathrm{CH}$ stress has been described for $\mathrm{R}$. stolonifer, where the amount of membrane proteins decreases to about $50 \%$, as well as the activity of H + ATPase [35]. Under several stress conditions, fungi are able to modify the composition of their cell membrane, accumulate glycogen as a secondary energy source, and express, overexpress, and/or repress several genes for kinases, enzymes, transcriptional factors, detoxification systems, and mediators of apoptosis [36-41]. In fungi, chitin derivatives increased proteins for ergosterol synthesis, actin cytoskeleton organization, protein $N$-glycosylation, endocytosis, cell wall formation, and carbohydrate metabolism [28]. Previously, it has been demonstrated that chitosan produces a fungal stress response, involving a large number of genes mediated by the action of common stress transcription factors in yeast, such as Msn2p and Msn4p [42]. It is therefore possible that in U. maydis, the same factors are involved in the stress response to $\mathrm{CH}, \mathrm{OCH}$, and $\mathrm{GCH}$.

Our results demonstrated that chitosan and its derivatives produce stress responses in $U$. maydis; these responses are significantly different depending on the characteristics of the molecule. Further experiments are necessary to establish the mode of action of these polycationic compounds and the stress response they elicit in fungi.

\section{Materials and Methods}

\subsection{Reagents and Solutions}

Low molecular weight chitosan (deacetylation degree (DD) $\geq 85 \%$, MW 50-190 kDa), oligochitosan (chitosan oligosaccharide lactate, DD > 90\%, average MW $5 \mathrm{kDa}$ ), and glycol chitosan (DD $\geq 60 \%$, average MW $250 \mathrm{kDa}$ ) were purchased from Sigma-Aldrich (St. Louis, MO, USA). The stock solutions of $\mathrm{CH}, \mathrm{OCH}$, and GCH were prepared according to our previously published protocol [15]. All chemical compounds and solvents were analytical grade.

\subsection{Growth in Isosmolar Medium}

Ustilago maydis ATCC 201384 FB2 was grown in minimal medium (1\% glucose, 0.3\% potassium nitrate, and salt solution, $\mathrm{pH}$ 5.6), individually or in the presence of $1 \mathrm{mg} \mathrm{CH}, \mathrm{OCH}$, or GCH per $\mathrm{mL}$. To establish an isosmolar environment, $400 \mathrm{mM}$ sorbitol was added. This isosmolar medium was prepared considering the intracellular potassium concentration and its counter anions of the model yeast Saccharomyces cerevisiae [43]. Cells were cultured at $28{ }^{\circ} \mathrm{C}$ under agitation at $130 \mathrm{rpm}$ for $48 \mathrm{~h}$. Growth was measured by the changes in optical density at $600 \mathrm{~nm}$.

\subsection{Transmembrane Potential}

Yeasts of $U$. maydis were cultured in YPD ( $1 \%$ yeast extract, $0.15 \%$ ammonium nitrate, $0.25 \%$ bacto peptone, $1 \%$ glucose, $\mathrm{pH}$ 6.8) for $24 \mathrm{~h}$ under the condition previously described [15]. Biomass was centrifuged at $3000 \times g$ for $10 \mathrm{~min}$ and diluted to $50 \%(w / v)$ with distilled water; $10-\mu \mathrm{L}$ samples were used. The membrane potential was estimated by following the changes in fluorescence of a $0.25 \mathrm{mM}$ 
cyanine solution at 540-590 nm, according to the protocol previously described by Peña et al. [25]. Increasing concentrations of each chitosan derivative (from 2 to $100 \mu \mathrm{g} \cdot \mu \mathrm{L}^{-1}$ ) were added after $50 \mathrm{~s}$ and the effects on the transmembrane potential were monitored.

\section{4. $\mathrm{H}_{2} \mathrm{O}_{2}$ Production Measured by the Amplex Red ${ }^{\circledR}$ Method}

Cells were cultured $\left(24 \mathrm{~h} / 130 \mathrm{rpm} / 28^{\circ} \mathrm{C}\right)$ in minimal media and with or without $1 \mathrm{mg}$ polycation $\mathrm{mL}^{-1}$. The cells were collected by centrifugation and a $50 \%(w / v)$ cell suspension was prepared with sterilized water. Subsequently, $20-\mu \mathrm{L}$ aliquots were placed into an ELISA 100-well plate with $50 \mu \mathrm{L}$ of reaction mixture $\left(0.1\right.$ units $\mathrm{mL}^{-1}$ horseradish peroxidase, 100 units $\mathrm{mL}^{-1}$ superoxide dismutase, $10 \mu \mathrm{M}$ Amplex red $^{\circledR}$ (Thermo Fisher Scientific, Waltham, MA, USA), $0.6 \mathrm{M}$ mannitol, and $5 \mathrm{mM}$ MES) and the volume was adjusted to $100 \mu \mathrm{L}$. The mixture was incubated at room temperature for $5 \mathrm{~min}$. The formation of the fluorescence derivative (resorufin) as a consequence of the release of $\mathrm{H}_{2} \mathrm{O}_{2}$ was measured in a PolarStar OMEGA detector (571-585 nm), using the OMEGA control software (Ortenberg, Germany); the results were interpolated against a calibration curve [44]. The data are reported as nmol of $\mathrm{H}_{2} \mathrm{O}_{2}$ per min per mg wet weight of cells.

\subsection{Catalase Activity}

We also used $U$. maydis to measure catalase in cells grown in the absence or presence of each chitosan derivative. Cells were collected by centrifugation and mechanically disrupted in $0.1 \mathrm{M}$ phosphate buffer ( $\mathrm{pH}$ 7), using $0.5 \mathrm{~mm}$ glass beads. Subsequently, $100 \mu \mathrm{L}$ of the supernatant were taken and added to $1.5 \mathrm{~mL}$ phosphate buffer. After this, $1 \mathrm{~mL}$ of $5 \mathrm{mM}$ hydrogen peroxide was added and catalase activity was measured by the decrease in absorbance at $240 \mathrm{~nm}$ after $10 \mathrm{~min}$. Protein was quantified by the Lowry method [45]. The specific activity of catalase is reported as units per mg protein. One unit is defined as the amount of enzyme necessary to reduce the absorbance at a rate of 0.1 units per $\mathrm{mL}$ per minute [46].

\subsection{Mitochondrial Staining}

Ustilago maydis was grown in minimal medium supplemented with $1 \mathrm{mg} \cdot \mathrm{mL}^{-1}$ of each compound for $24 \mathrm{~h}$, under the conditions described before. Cell suspension aliquots of $1 \mathrm{~mL}$ were incubated in the presence of $25 \mathrm{nM}$ Mitotracker green ${ }^{\circledR}$ (Invitrogen/Thermo Fisher Scientific, Waltham, MA, USA) for $30 \mathrm{~min}$ at $37^{\circ} \mathrm{C}$. Untreated cells were used as control. Fluorescent mitochondria were observed in phase contrast microscopy with a fluorescein filter $(494-520 \mathrm{~nm})$ [47].

\subsection{Total Phospholipid Quantification}

The membrane fraction of $U$. maydis grown in the presence of each compound at a concentration of $1 \mathrm{mg} \cdot \mathrm{mL}^{-1}$ for 24 hours at $28^{\circ} \mathrm{C}$ was obtained by fractional centrifugation, as described in our previous publication [15]. For the quantification of total phospholipids, a commercial kit was used (Spinreact, Spain). Phospholipid concentration was determined by comparing the absorbance against a standard containing $300 \mathrm{mg} \cdot \mathrm{dL}^{-1}$ of total phospholipids. The results were expressed in $\mathrm{mM}$ phospholipids $\mathrm{g}$ of cells $^{-1}$ (wet weight).

\subsection{SDS-PAGE of the Membrane Fraction}

Cells were incubated for $24 \mathrm{~h}$ on a shaker in the presence of each compound at $1 \mathrm{mg} \cdot \mathrm{mL}^{-1}$, with the exception of $\mathrm{CH}$, which was added at $10 \mu \mathrm{g} \cdot \mathrm{mL}^{-1}$. The membrane fraction was obtained and the Lowry method was used to determine the protein concentration. Samples with $\approx 30 \mu \mathrm{g}$ of protein were mixed with $4 \times$ loading buffer $(0.5 \mathrm{M}$ Tris $\mathrm{pH} 6.8 ; 10 \%$ SDS; $15 \% \beta$-mercaptoethanol, $25 \%$ glycerol, and $0.1 \mathrm{mg} \cdot \mathrm{mL}^{-1}$ bromophenol blue) and analyzed on 10\% SDS-PAGE; staining and de-staining were performed with Coomassie Blue and acetic acid-methanol-water (1:2:10) solution, respectively. 


\subsection{Glycogen Accumulation and PAS Staining}

Ustilago maydis was fixed with $0.6 \%$ periodic acid solution for $10 \mathrm{~min}$ at room temperature. The sample was washed with distilled water and mixed with Schiff's reagent (leucobasic fuchsin) for $30 \mathrm{~min}$. Subsequently, the samples were washed three times with $10 \%$ sodium metabisulfite- $1 \mathrm{~N} \mathrm{HCl}$ for $1 \mathrm{~min}$. Samples were rinsed with an ethanol-xylene mixture, mounted on a slide with synthetic resin, and observed in an optical microscope, denoting a purple color in the case of glycogen presence.

Acknowledgments: Special thanks to Escuela Nacional de Ciencias Biológicas of Instituto Politécnico Nacional; Facultad de medicina and Instituto de Fisiología Celular of Universidad Nacional Autónoma de México for the support for carrying out this work. This research received financial support from CONACyT projects No. 256520 and 254904; DGAPA-PAPIIT project IN222117 and IPN-SIP-ENCB projects No. 20141521, No. 20160999 and No. 20170864. The first author was recipient of a Ph.D. fellowship provided by CONACyT (No. 231581). For the publication as an open access article, this research had financial support by CONACyT project No. 256520 and 254904; grants CONACyT 239587 and DGAPA-PAPIIT IN204015 to SUC.

Author Contributions: D.R.O.-H. and G.G.-S. conceived and designed the experiments; J.P.P. designed isosmolar media experiments; D.R.O.-H. performed the experiments; C.U.-A. and S.U.-C. performed ROS quantification; S.U.-C. and C.U.-A. contributed reagents and analysis tools; D.R.O.-H. and G.G.-S. wrote the paper; J.P.P. and S.U.-C. reviewed and corrected the document.

Conflicts of Interest: The authors declare no conflict of interest. The founding sponsors had no role in the design of the study; in the collection, analyses, or interpretation of data; in the writing of the manuscript, and in the decision to publish the results.

\section{References}

1. Martin, F.; Cullen, D.; Hibbett, D.; Pisabarro, A.; Spatafora, J.W.; Baker, S.E.; Grigoriev, I.V. Sequencing the fungal tree of life. New Phytol. 2011, 190, 818-821. [CrossRef] [PubMed]

2. Lackner, D.H.; Schmidt, M.W.; Wu, S.; Wolf, D.A.; Bähler, J. Regulation of transcriptome, translation, and proteome in response to environmental stress in fission yeast. Genome Biol. 2012, 13, R25. [CrossRef] [PubMed]

3. Ortiz-Urquiza, A.; Keyhani, N.O. Stress response signaling and virulence: Insights from entomopathogenic fungi. Curr. Genet. 2015, 61, 239-249. [CrossRef] [PubMed]

4. Gasch, A.P. Comparative genomics of the environmental stress response in ascomycete fungi. Yeast 2007, 24, 961-976. [CrossRef] [PubMed]

5. Tesei, D.; Marzban, G.; Zakharova, K.; Isola, D.; Selbmann, L.; Sterflinger, K. Alteration of protein patterns in black rock inhabiting fungi as a response to different temperatures. Fungal Biol. 2012, 116, 932-940. [CrossRef] [PubMed]

6. Francois, J.M.; Formosa, C.; Schiavone, M.; Pillet, F.; Martin-Yken, H.; Dague, E. Use of atomic force microscopy (afm) to explore cell wall properties and response to stress in the yeast saccharomyces cerevisiae. Curr. Genet. 2013, 59, 187-196. [CrossRef] [PubMed]

7. Gunde-Cimerman, N.; Plemenitaš, A.; Buzzini, P. Changes in lipids composition and fluidity of yeast plasma membrane as response to cold. In Cold-Adapted Yeasts: Biodiversity, Adaptation Strategies and Biotechnological Significance; Buzzini, P., Margesin, R., Eds.; Springer: Berlin/Heidelberg, Germany, 2014; pp. 225-242.

8. Lushchak, V.I. Adaptive response to oxidative stress: Bacteria, fungi, plants and animals. Comp. Biochem. Physiol. Part C Toxicol. Pharmacol. 2011, 153, 175-190. [CrossRef] [PubMed]

9. Hernández-Oñate, M.A.; Herrera-Estrella, A. Damage response involves mechanisms conserved across plants, animals and fungi. Curr. Genet. 2015, 61, 359-372.

10. Dash, M.; Chiellini, F.; Ottenbrite, R.M.; Chiellini, E. Chitosan-A versatile semi-synthetic polymer in biomedical applications. Prog. Polym. Sci. 2011, 36, 981-1014. [CrossRef]

11. Bautista-Baños, S.; Hernández-Lauzardo, A.N.; Velázquez-del Valle, M.G.; Hernández-López, M.; Ait Barka, E.; Bosquez-Molina, E.; Wilson, C.L. Chitosan as a potential natural compound to control pre and postharvest diseases of horticultural commodities. Crop Prot. 2006, 25, 108-118.

12. Vinsova, J.; Vavrikova, E. Chitosan derivatives with antimicrobial, antitumour and antioxidant activities-A review. Curr. Pharma. Des. 2011, 17, 3596-3607. [CrossRef] 
13. Benhabiles, M.S.; Salah, R.; Lounici, H.; Drouiche, N.; Goosen, M.F.A.; Mameri, N. Antibacterial activity of chitin, chitosan and its oligomers prepared from shrimp shell waste. Food Hydrocoll. 2012, 29, 48-56. [CrossRef]

14. Raafat, D.; Sahl, H.-G. Chitosan and its antimicrobial potential-A critical literature survey. Microb. Biotechnol. 2009, 2, 186-201. [CrossRef] [PubMed]

15. Olicón-Hernández, D.R.; Hernández-Lauzardo, A.N.; Pardo, J.P.; Peña, A.; Velázquez-del Valle, M.G.; Guerra-Sánchez, G. Influence of chitosan and its derivatives on cell development and physiology of Ustilago maydis. Int. J. Biol. Macromol. 2015, 79, 654-660.

16. Ma, Z.; Yang, L.; Yan, H.; Kennedy, J.F.; Meng, X. Chitosan and oligochitosan enhance the resistance of peach fruit to brown rot. Carbohydr. Polym. 2013, 94, 272-277. [CrossRef] [PubMed]

17. Gupta, K.; Dey, A.; Gupta, B. Plant polyamines in abiotic stress responses. Acta Physiol. Plant. 2013, 35, 2015-2036. [CrossRef]

18. Liu, L.; Zhou, Y.; Zhao, X.; Wang, H.; Wang, L.; Yuan, G.; Asim, M.; Wang, W.; Zeng, L.; Liu, X.; et al. Oligochitosan stimulated phagocytic activity of macrophages from blunt snout bream (megalobrama amblycephala) associated with respiratory burst coupled with nitric oxide production. Dev. Comp. Immunol. 2014, 47, 17-24. [CrossRef] [PubMed]

19. Xu, J.; Zhao, X.; Wang, X.; Zhao, Z.; Du, Y. Oligochitosan inhibits phytophthora capsici by penetrating the cell membrane and putative binding to intracellular targets. Pestic. Biochem. Physiol. 2007, 88, 167-175. [CrossRef]

20. Lopez-Moya, F.; Colom-Valiente, M.F.; Martinez-Peinado, P.; Martinez-Lopez, J.E.; Puelles, E.; Sempere-Ortells, J.M.; Lopez-Llorca, L.V. Carbon and nitrogen limitation increase chitosan antifungal activity in neurospora crassa and fungal human pathogens. Fungal Biol. 2015, 119, 154-169. [CrossRef] [PubMed]

21. Martinez, L.R.; Mihu, M.R.; Tar, M.; Cordero, R.J.B.; Han, G.; Friedman, A.J.; Friedman, J.M.; Nosanchuk, J.D. Demonstration of antibiofilm and antifungal efficacy of chitosan against candidal biofilms, using an in vivo central venous catheter model. J. Infect. Dis. 2010, 201, 1436-1440. [CrossRef] [PubMed]

22. Cota-Arriola, O.; Cortez-Rocha, M.O.; Rosas-Burgos, E.C.; Burgos-Hernández, A.; López-Franco, Y.L.; Plascencia-Jatomea, M. Antifungal effect of chitosan on the growth of aspergillus parasiticus and production of aflatoxin b1. Polym. Int. 2011, 60, 937-944. [CrossRef]

23. Xing, K.; Zhu, X.; Peng, X.; Qin, S. Chitosan antimicrobial and eliciting properties for pest control in agriculture: A review. Agron. Sustain. Dev. 2015, 35, 569-588. [CrossRef]

24. Dean, R.; Van Kan, J.A.L.; Pretorius, Z.A.; Hammond-Kosack, K.E.; Di Pietro, A.; Spanu, P.D.; Rudd, J.J.; Dickman, M.; Kahmann, R.; Ellis, J.; et al. The top 10 fungal pathogens in molecular plant pathology. Mol. Plant Pathol. 2012, 13, 414-430. [CrossRef] [PubMed]

25. Peña, A.; Uribe, S.; Pardo, J.P.; Borbolla, M. The use of a cyanine dye in measuring membrane potential in yeast. Arch. Biochem. Biophys. 1984, 231, 217-225.

26. Hernández, A.; Cooke, D.T.; Clarkson, D.T. In vivo activation of plasma membrane h+-atpase hydrolytic activity by complex lipid-bound unsaturated fatty acids in Ustilago maydis. Eur. J. Biochem. 2002, 269, 1006-1011.

27. Shor, E.; Perlin, D.S. Coping with stress and the emergence of multidrug resistance in fungi. PLoS Pathog. 2015, 11, e1004668. [CrossRef] [PubMed]

28. Zakrzewska, A.; Boorsma, A.; Delneri, D.; Brul, S.; Oliver, S.G.; Klis, F.M. Cellular processes and pathways that protect saccharomyces cerevisiae cells against the plasma membrane-perturbing compound chitosan. Eukaryot. Cell. 2007, 6, 600-608. [CrossRef] [PubMed]

29. Krantz, M.; Becit, E.; Hohmann, S. Comparative genomics of the hog-signalling system in fungi. Curr. Genet. 2006, 49, 137-151. [CrossRef] [PubMed]

30. Hernández-Lauzardo, A.N.; Vega-Pérez, J.; Velázquez-del Valle, M.G.; Sánchez, N.S.; Peña, A.; Guerra-Sánchez, G. Changes in the functionality of plasma membrane of rhizopus stolonifer by addition of chitosan. J. Phytopathol. 2011, 159, 563-568.

31. Pena, A.; Sanchez, N.S.; Calahorra, M. Effects of chitosan on candida albicans: Conditions for its antifungal activity. BioMed Res. Int. 2013, 2013, 15. [CrossRef] [PubMed]

32. Palma-Guerrero, J.; Lopez-Jimenez, J.A.; Pérez-Berná, A.J.; Huang, I.C.; Jansson, H.B.; Salinas, J.; Villalaín, J.; Read, N.D.; Lopez-Llorca, L.V. Membrane fluidity determines sensitivity of filamentous fungi to chitosan. Mol. Microbiol. 2010, 75, 1021-1032. [CrossRef] [PubMed] 
33. Alfaro-Gutiérrez, I.C.; Guerra-Sánchez, M.G.; Hernández-Lauzardo, A.N.; Velázquez-del Valle, M.G. Morphological and physiological changes on rhizopus stolonifer by effect of chitosan, oligochitosan or essential oils. J. Phytopathol. 2014, 162, 723-730.

34. Lopez-Moya, F.; Kowbel, D.; Nueda, M.J.; Palma-Guerrero, J.; Glass, N.L.; Lopez-Llorca, L.V. Neurospora crassa transcriptomics reveals oxidative stress and plasma membrane homeostasis biology genes as key targets in response to chitosan. Mol. BioSyst. 2016, 12, 391-403. [CrossRef] [PubMed]

35. García-Rincón, J.; Vega-Pérez, J.; Guerra-Sánchez, M.G.; Hernández-Lauzardo, A.N.; Peña-Díaz, A.; Velázquez-Del Valle, M.G. Effect of chitosan on growth and plasma membrane properties of rhizopus stolonifer (ehrenb.:Fr.) vuill. Pestic. Biochem. Physiol. 2010, 97, 275-278.

36. Cannon, R.D.; Lamping, E.; Holmes, A.R.; Niimi, K.; Tanabe, K.; Niimi, M.; Monk, B.C. Candida albicans drug resistance-Another way to cope with stress. Microbiology 2007, 153, 3211-3217. [CrossRef] [PubMed]

37. Kroll, K.; Pähtz, V.; Kniemeyer, O. Elucidating the fungal stress response by proteomics. J. Proteom. 2014, 97, 151-163. [CrossRef] [PubMed]

38. Smith, D.A.; Morgan, B.A.; Quinn, J. Stress signalling to fungal stress-activated protein kinase pathways. FEMS Microbiol. Lett. 2010, 306, 1-8. [CrossRef] [PubMed]

39. Hayes, B.M.E.; Anderson, M.A.; Traven, A.; van der Weerden, N.L.; Bleackley, M.R. Activation of stress signalling pathways enhances tolerance of fungi to chemical fungicides and antifungal proteins. Cell. Mol. Life Sci. 2014, 71, 2651-2666. [CrossRef] [PubMed]

40. Kim, J.H.; Campbell, B.C.; Yu, J.; Mahoney, N.; Chan, K.L.; Molyneux, R.J.; Bhatnagar, D.; Cleveland, T.E. Examination of fungal stress response genes using saccharomyces cerevisiae as a model system: Targeting genes affecting aflatoxin biosynthesis by aspergillus flavus link. Appl. Microbiol. Biotechnol. 2005, 67, 807-815. [CrossRef] [PubMed]

41. Freitas, F.Z.; Virgilio, S.; Cupertino, F.B.; Kowbel, D.J.; Fioramonte, M.; Gozzo, F.C.; Glass, N.L.; Bertolini, M.C. The SEB-1 transcription factor binds to the STRE motif in Neurospora crassa and regulates a variety of cellular processes including the stress response and reserve carbohydrate metabolism. G3 Genes Genomes Genet. 2016, 6, 1327-1343. [CrossRef] [PubMed]

42. Zakrzewska, A.; Boorsma, A.; Brul, S.; Hellingwerf, K.J.; Klis, F.M. Transcriptional response of saccharomyces cerevisiae to the plasma membrane-perturbing compound chitosan. Eukaryot. Cell 2005, 4, 703-715. [CrossRef] [PubMed]

43. Navarrete, C.; Petrezsélyová, S.; Barreto, L.; Martínez, J.L.; Zahrádka, J.; Ariño, J.; Sychrová, H.; Ramos, J. Lack of main $k+$ uptake systems in saccharomyces cerevisiae cells affects yeast performance in both potassium-sufficient and potassium-limiting conditions. FEMS Yeast Res. 2010, 10, 508-517. [CrossRef] [PubMed]

44. Guerrero-Castillo, S.; Cabrera-Orefice, A.; Vázquez-Acevedo, M.; González-Halphen, D.; Uribe-Carvajal, S. During the stationary growth phase, yarrowia lipolytica prevents the overproduction of reactive oxygen species by activating an uncoupled mitochondrial respiratory pathway. Biochim. Biophys. Acta 2012, 1817, 353-362. [CrossRef] [PubMed]

45. Lowry, O.H.; Rosebrough, N.J.; Farr, A.L.; Randall, R.J. Protein measurement with the folin phenol reagent. J. Biol. Chem. 1951, 193, 265-275. [PubMed]

46. Li, Y.; Schellhorn, H.E. Rapid kinetic microassay for catalase activity. J. Biomol. Tech. JBT 2007, 18, $185-187$. [PubMed]

47. Pham, C.D.; Yu, Z.; Sandrock, B.; Bölker, M.; Gold, S.E.; Perlin, M.H. Ustilago maydis rho1 and 14-3-3 homologues participate in pathways controlling cell separation and cell polarity. Eukaryot. Cell 2009, 8, 977-989. [CrossRef] [PubMed]

Sample Availability: Samples of the compounds chitosan, oligochitosan and glycol-chitosan are not available from the authors.

(C) 2017 by the authors. Licensee MDPI, Basel, Switzerland. This article is an open access article distributed under the terms and conditions of the Creative Commons Attribution (CC BY) license (http://creativecommons.org/licenses/by/4.0/). 